\title{
Evaluation of Intensive Care Unit Infections in Kafkas University Hospital - A 5 Years Analysis
}

\author{
Kafkas Üniversitesi Hastanesi Yoğun Bakım Enfeksiyonlarının Değerlendirilmesi \\ -5 Yıllık Analiz
}

\author{
Abdullah Gumus, Cigdem Eda Balkan Bozlak \\ Department of Medical Microbiology, Kafkas University Faculty of Medicine, Kars, Turkey
}

\begin{abstract}
Aim: Nosocomial infections (NIs) increase the length of hospital stay and mortality/morbidity rates, and lead to increased treatment related to hospital services and intensive care unit. In this study, we aimed to retrospectively evaluate patients admitted to the adult intensive care unit of our hospital who were diagnosed with NIs.
\end{abstract}

Material and Method: Between January-2015 and July-2019, 680 patients hospitalized in the intensive care unit of Kafkas University Medical Faculty Hospital and diagnosed with NIs according to the Centers for Disease Control and Prevention criteria were retrospectively evaluated. A total of 2.880 samples taken from the patients were sent to the medical microbiology laboratory, where microorganism identification was performed using conventional microbiological methods and the BD Phoenix automatic microorganism identification system.

Results: The mean age of the patients was $71.47 \pm 16.74$ years. The samples were mostly collected from blood ( $n=1.305)$, followed by urine $(n=520)$, tracheal aspirate $(n=273)$, and sputum ( $n=108)$. Sixty-two percent of the microorganisms causing HE were Gram (+) bacteria, 29\% were Gram (-) bacteria, and 1.5\% were yeasts. The most commonly isolated Gram (-) microorganisms were Escherichia coli (10\%), Pseudomonas aeruginosa (8.3\%), Klebsiella pneumoniae (5.4\%), and Acinetobacter baumannii (4.5\%). In addition, VRE was detected in two patients, and MRSA in three patients.

Conclusion: Nasocomial infections are an important health problem in Turkey, as well as in the world. It has a great importance for each healthcare institutions to share its own data in order to ensure the rational use of antibiotics. Therefore, regular surveillance studies are very important for the control of these infections.

Key words: intensive care unit; nasocomial infections; surveillance
ÖZET

Amaç: Hastane enfeksiyonları (HE), hastanın hastanede ve yoğun bakımdaki yatıs süresinin, mortalite/morbidite oranlarının ve tedavi maliyetinin artmasına neden olmaktadır. Bu çalıșmada, üniversitemiz hastanesi yetișkin yoğun bakımına yatmıș ve hastane enfeksiyonu tespit edilen hastaların retrospektif olarak incelenmesi amaçlanmıștır.

Materyal ve Metot: Ocak-2015 ile Temmuz-2019 tarihleri arasında Kafkas Üniversitesi Tıp Fakültesi Hastanesi yetișkin yoğum bakım servisine yatmıș, Centers for Disease Control and Prevention (CDC) kriterlerine göre HE tanısı konmuș 680 hasta retrospektif olarak değerlendirmeye alınmıștır. Altı yüz seksen hastadan alınan 2880 örnek, Tıbbi Mikrobiyoloji Laboratuvarına gönderilmiș ve bu örneklerde konvansiyonel mikrobiyolojik yöntemler ve gerektiği durumlarda $B D$ Phoenix otomatik mikroorganizma tanımlama sistemi kullanılarak mikroorganizma identifikasyon testleri yapılmıștır.

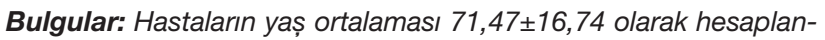
mıștır. Hastalardan en çok alınan örnekler; kan ( $n=1,305)$, trakeal aspirat ( $n=273)$, idrar $(n=520)$ ve balgam $(n=108)$ örnekleridir. HE'ye neden olan mikroorganizmaların \%62'si Gram (+), \%29'u Gram (-) bakteriler ve \%1,5 mayalardan olușmaktaydı. En sık izole edilen Gram (-) mikroorganizmalar Escherichia coli (\%10), Pseudomonas aeruginosa $(\% 8,3)$, Klebsiella pneumoniae $(\% 5,4)$ ve Acinetobacter baumannii $(\% 4,5)$ olarak tespit edilmiștir. Ayrıca 2 hastada VRE ve 3 hastada MRSA tespit edilmiștir.

Sonuç: Hastane enfeksiyonları tüm dünyada olduğu gibi ülkemizde de önemli bir sağlık sorunudur. Her sağlık kurulușunun özellikle hastane enfeksiyonlarına karșı akılcı antibiyotik kullanımını sağlamak amacı ile kendi verilerini paylașması büyük önem arz etmektedir. Bu sebepten düzenli olarak gerçekleștirilen sürveyans çalıșmaları, bu enfeksiyonların kontrolünün sağlanmasındaki en önemli faktörlerden biridir.

Anahtar kelimeler: yoğun bakım ünitesi; hastane enfeksiyonlarl; surveyans

Iletișim/Contact: Abdullah Gumus, Kafkas University, Faculty of Medicine, Department of Medical Microbiology, Kars, Turkey • Tel: 05423381299 • E-mail:abdullahgumus59@hotmail.com • Geliș/Received: 19.11.2019 • Kabul/Accepted: 13.05.2020

ORCID: Abdullah Gümüş, 0000-0002-7762-4634 • Çiğdem Eda Balkan Bozlak, 0000-0003-3922-7758 


\section{Introduction}

Nosocomial infections (NIs), also known as hospitalacquired infections, are those contracted from the environment or staff of a healthcare facility ${ }^{1}$. They can spread in various hospital environments, including nursing homes, wards, operating rooms, or other clinical settings. Infection happens in a clinical setting through a large number of pathways. In addition to contaminated equipment, bedding articles, or aerosols, staff can also spread the infection ${ }^{2}$. An epidemiological investigation conducted by WHO in 55 hospitals in 14 countries from four WHO Regions (Europe, Eastern Mediterranean, South East Asia, and Western Pacific) revealed that an average of $8.7 \%$ of hospitalized patients had a hospital infection. Moreover, 1.4 million people around the world suffer from infectious complications acquired in hospitals ${ }^{3}$. The morbidity rates associated with NIs are reported as 7.7, 11.8, 10.0, and 9.0\% for hospitals located in the European, Eastern Mediterranean, South-East Asia and Western Pacific, respectively ${ }^{4}$. Hospital infections can lead to functional disability and mental stress in patients. In addition, they are also one of the leading causes of death ${ }^{1}$

Healthcare systems in many countries began implementing comprehensive multicomponent infection control surveillance and intervention campaigns in the mid-2000 s. These campaigns included vertical measures that targeted specific organisms and devicerelated healthcare-associated infections due to vascular and urinary catheters and intubation, in addition to general measures, such as increasing hand hygiene compliance and hospital cleaning ${ }^{3}$.

The intensive care unit (ICU) has been a long-standing focus of attention for reducing largely preventable healthcare-associated infections because the prevalence of infections acquired in ICU is higher than it is in other hospital units. This might be due to the severity of disease and prolonged stay of the patients requiring intensive care ${ }^{1}$. Furthermore, critically ill infants who receive care in a neonatal ICU (NICU) have an increased risk of NIs due to immunological immaturity and invasive diagnostic and therapeutic procedures 5 . Prior surveillance studies have shown that the rates of NIs in NICUs range from $8.7 \%$ to $74.3 \%{ }^{6,7}$. Despite the use of various infection control strategies, such as prophylactic antibiotics, immunoglobulins, and physical barriers, the prevalence of NIs in NICUs remains high $^{8}$. For several decades, there has been controversy over whether the inanimate environment of an NICU is associated with the risk of NIs, but to date, only few studies have been conducted on this issue ${ }^{7-9}$.

Ventilator-associated pneumonia is the most common $\mathrm{NI}$ and one of the most frequent complications among patients admitted to hospitals, especially those requiring intensive care ${ }^{1,5}$.

Candidemia is a life-threatening condition with a high mortality ranging between 30 and $45 \%$. In candidemia, the length of hospital stay is often prolonged and the burden of hospitalization cost is high. Modern medicine and the growing complexity of surgical procedures have increased the risk of candidemia in various patient populations ${ }^{2}$.

In this study, our aim was to retrospectively determine the epidemiology of NIs that occurred in ICU of Kafkas University Health Research and Application Hospital and to present the first data from this hospital.

\section{Materials and Method}

\section{Hospital and Clinical Isolates}

This study was conducted at the microbiology laboratory of our university hospital between January 2015 and July 2019. The isolates were obtained from various clinical specimens collected, including urine, blood, fluid (pleural, pericardial, synovial and peritoneal), wound swab, tracheal secret, and nasal swab.

Patients admitted to the adult ICU and diagnosed with NIs according to the criteria of the Centers for Disease Control and Prevention were retrospectively evaluated.

\section{Bacteria Identification and Susceptibility Tests}

All clinical samples were cultured in 5\% sheep blood agar and eosin-methylene blue agar to obtain bacterial colonies. First, the bacterial colonies were identified by conventional methods, such as catalase, gram staining and coagulase tests. Then, a bacterial suspension (McFarland 0.5 ) was prepared and placed into the microorganism identification machine, Phoneix 100 BD Microorganism Identification System (Becton Dickinson, Diagnostic Instrument Systems, Sparks, USA), to confirm the data obtained by the conventional methods.

Antibiotic susceptibility tests were also first performed conventionally using the Kirby-Bauer disk diffusion method, and then the data were confirmed using the 
BD Phoenix Microorganism Identification System. The results were evaluated according to the standards of the European Committee on Antimicrobial Susceptibility Testing.

\section{Statistical Analysis}

All obtained data were analyzed using the Statistical Package for the Social Sciences (SPSS) software version 22.0 (SPSS Inc., Chicago, IL, USA). Number (n), percentage (\%), mean, standard deviation (SD), median, minimum and maximum values were given for the descriptive statistics.

\section{Results}

During the 42-month period from January 2015 to July 2019, a total of 2.880 samples of various cultures from 680 patients were sent to the microbiology laboratory of Kafkas University Health Research and Application Hospital from the ICU of our hospital. The samples were mostly collected from blood $(n=1.305)$, followed by urine $(n=520)$, tracheal aspirate $(n=273)$, and sputum $(n=108)$. Sixty-two percent of the microorganisms causing infections in ICU were identified as Gram (+) bacteria, 29\% as Gram (-) bacteria, and $1.5 \%$ as yeasts. The most commonly isolated Gram (-) microorganisms were Escherichia coli (10\%),
Pseudomonas aeruginosa (8.3\%), Klebsiella pneumoniae (5.4\%), and Acinetobacter baumannii (4.5\%), and the most commonly isolated Gram (+) microorganisms were coagulase-negative staphylococci (CNS) at $47 \%$, Enterococcus sp. at 5.3\%, and Staphylococcus aureus at $1.8 \%$ (Table 1, 2).

\section{Discussion}

Preventing NIs requires intensive surveillance and an organized hospital-wide infection control program. It is aimed to reduce hospital infections with the improvements and measures taken within the infection control committees. ${ }^{10,11}$. Although the implementation of effective and successful hospital programs can reduce the rate of NIs, they still constitute a problem. The epidemiological findings of NI reports among different hospitals vary within and between countries $^{10,12,13}$. The overall rate of NIs is $1.5-27 \%$, depending on the definitions used and severity of the population under study ${ }^{10,14}$. This study indicated that the rate of NIs in our hospital was at a very low level, which may be due to the absence of services for high-risk patients or a transplantation unit. However, our rates of NIs showed an increase in the last two years, which can be related to the modification undertaken in ICU, units. The unit has been completely renewed according

Table 1. Gram negative microorganisms isolated from the clinic samples of the intensive care units patients

\begin{tabular}{|c|c|c|c|c|c|c|c|c|c|}
\hline \multirow{3}{*}{$\begin{array}{l}\text { Clinic Material } \\
\text { Tracheal aspirate }\end{array}$} & \multirow{3}{*}{$\begin{array}{c}\text { Total Sample } \\
\text { Number }\end{array}$} & \multicolumn{8}{|c|}{ Microorganisms } \\
\hline & & \multicolumn{2}{|c|}{ Acinetobacter baumannii } & \multicolumn{2}{|c|}{ Pseudomonas aeruginosa } & \multicolumn{2}{|c|}{ Escherichia coli } & \multicolumn{2}{|c|}{ Klebsiella pneumoniae } \\
\hline & & 34 & $12 \%$ & 83 & $30 \%$ & 36 & $13 \%$ & 27 & $10 \%$ \\
\hline Urine & 520 & 3 & $0.5 \%$ & 15 & $3 \%$ & 114 & $22 \%$ & 32 & $6 \%$ \\
\hline Sputum & 108 & 25 & $23 \%$ & 26 & $24 \%$ & 24 & $22 \%$ & 18 & $16 \%$ \\
\hline Blood culture & 1305 & 39 & $3 \%$ & 59 & $4.5 \%$ & 61 & $4.7 \%$ & 44 & $3.4 \%$ \\
\hline Total & 2206 & 101 & $4.5 \%$ & 183 & $8.3 \%$ & 235 & $10 \%$ & 121 & $5.4 \%$ \\
\hline
\end{tabular}

Table 2. Yeast and gram positive microorganisms isolated from the clinic samples of the intensive care units patients

\begin{tabular}{|c|c|c|c|c|c|c|c|c|c|}
\hline \multirow{3}{*}{$\frac{\text { Clinic Material }}{\text { Tracheal Aspirate }}$} & \multirow{3}{*}{$\begin{array}{c}\begin{array}{c}\text { Total Sample } \\
\text { Number }\end{array} \\
273\end{array}$} & \multicolumn{8}{|c|}{ Microorganisms } \\
\hline & & \multicolumn{2}{|c|}{ Enterococcus sp. } & \multicolumn{2}{|c|}{ Staphylococcus aureus } & \multicolumn{2}{|c|}{$\begin{array}{c}\text { Coagulase negative } \\
\text { staphylococcus }\end{array}$} & \multicolumn{2}{|c|}{ Candida sp. } \\
\hline & & 14 & $5 \%$ & 21 & $8 \%$ & 68 & $25 \%$ & 0 & $0 \%$ \\
\hline Urine & 520 & 37 & $7 \%$ & 1 & $0.1 \%$ & 10 & $2 \%$ & 32 & $6 \%$ \\
\hline Sputum & 108 & 0 & $0 \%$ & 6 & $6 \%$ & 8 & $7 \%$ & 1 & $0.9 \%$ \\
\hline Blood Culture & 1305 & 67 & $5 \%$ & 12 & $0.9 \%$ & 945 & $72 \%$ & 6 & $0.5 \%$ \\
\hline Total & 2206 & 118 & $5.3 \%$ & 40 & $1.8 \%$ & 1031 & $47 \%$ & 39 & $1.7 \%$ \\
\hline
\end{tabular}


to the latest technology. ICUs are one of the most risky units in a hospital in terms of the rapid spread of resistant bacterial strains and NIs ${ }^{11}$. The detection of NIs in ICUs is necessary to determine appropriate treatment approaches and epidemiologic characteristics. Moreover, identification of antibiotic susceptibilities and bacterial agents is very important to reduce the rates of associated mortality and morbidity ${ }^{14}$.

In a large clinical study, "European Prevalence of Infection in Intensive Care (EPIC II)", which was conducted in 1.265 ICUs from 75 countries, $47 \%$ of the isolates analyzed were identified as gram positive bacteria, $62 \%$ as gram negative bacteria, and $19 \%$ as yeast, these data showed that Gram-negative bacteria were generally isolated from ICUs ${ }^{15}$. In contrast, in our study, gram positive bacteria were mostly identified. When we examined the distribution of Grampositive bacteria isolated from our ICU, CNS and Enterococcus spp. were the most isolated microorganisms. Therefore, our data are not consistent with the current literature in terms of the isolation rates of bacterial strains. According to the National Nosocomial Infections Surveillance report, Enterococcus sp. and Staphylocuccus aureus were most isolated from clinical samples, and most of these bacteria were isolated from the blood samples of the patients hospitalized in $\mathrm{ICU}^{16}$. In our study, we identified CNS at the highest rate, followed by Enterococcus spp. . According to the literature, Enterococcus strains are the second most common agent after $S$. aureus for NIs. Intrinsic and acquired resistance to most antibiotics in Enterococci may cause critical problems in the terms of the increasing Enterococci isolation frequency ${ }^{17}$.

The majority of the bacteria isolated from ICUs, such as Gram-positive $S$. aureus, MRSA, MRCNS and Enterococcus spp. and Gram-negative Acinetobacter spp., Klebsiella spp. and E. coli show resistance to most antimicrobial agents, especially colistin and tigecycline across the globe. The extensive use of broad-spectrum antibiotics can lead to the multidrug-resistant bacteria in patients who develop infections in ICU. Moreover, the general state of ICU patients, requirement of longer hospital stay, presence of underlying disease, and application of more surgical procedures are among the reasons for the growing number of resistant bacteria ${ }^{18-20}$.

In a study conducted by Inan et al. ${ }^{20}$ in the ICU of Akdeniz University, the most common Gram (-) and Gram (+) bacteria were identified as $P$. aeruginosa $S$. aureus, respectively. In another study conducted in the
ICU of Dicle University, Geyik et al. ${ }^{21}$ reported that E. coli (26\%) was the most frequently seen Gram (-) bacterium while CNS was the most common Gram (+) bacterium (14\%). At Van Yuzuncu Yil University Research and Application Hospital, Karahocagil et al. ${ }^{22}$ determined A. baumannii as the leading cause of NIs at a rate of $23.2 \%$, followed by Klebsiella spp at $20.5 \%$, E. coli at $19.6 \%$, and Pseudomonas spp. at $11.6 \%$. In our study, the most cultured Gram (-) bacteria were $E$. coli (10\%), P. aeruginosa (8.3\%), $K$. pneumoniae (5.4\%), and A. baumannii (4.5\%) while the most commonly isolated Gram (+) microorganisms were CNS at 47\%, Enterococcus sp. at 5.3\%, and Staphylococcus aureus at $1.8 \%$.

NIs are a cause of increased mortality, morbidity and resource expenditure in the hospital environment, especially ICU. A multidisciplinary approach to prevention that involves the whole intensive care staff, including management is essential if we are to succeed in minimizing NIs. Raising awareness of risk factors and paying attention to simple measures, such as hand hygiene can decrease the effect and incidence of these infections. Currently, treatment relies on an appropriate antibiotic treatment ideally managed in association with infectious disease specialists to decrease the risks of antimicrobial resistance. Surveillance of NIs is increasingly undertaken, which will play an important part in the monitoring of such infections and the assessment of strategies to prevent their development.

\section{References}

1. Maki DG, Alvarado CJ, Hassemer CA, Zilz MA. Relation of the inanimate hospital environment to endemic nosocomial infection. N Engl J Med 1982;16:1562-6.

2. Rosenthal VD, Maki DG, Graves N. The International Nosocomial Infection Control Consortium (INICC): Goals and objectives, description of surveillance methods, and operational activities. Am J Infect Control. 2008;36:1-12.

3. Mayon-White RT, Ducel G, Kereselidze T. And Tikomirov E. An international survey of the prevalence of hospital-acquired infection. Jounal of Hospital İnfection 1988;11:43-48.

4. Ponce-de-Leon $S$, The needs of developing countries and the resources required. Journal of Hospital İnfection 1991;18:376381.

5. Ye L, Zhenyu G, Ye L, Guoqing H, Ran C, Zhiping C. Impact of nosocomial infections surveillance on nosocomial infection rates: A systematic review. International Journal of Surgery 2017;42:164-169. 
6. Cura C, Ozen M, Akaslan Kara A, Alkan G, Sesli Cetin E. Health careeassociated infection surveillance in a tertiary neonatal intensive care unit: A prospective clinical study after moving to a new building. American Journal of Infection Control 2016;44:80-4.

7. Dennis G, Maki MD, Carla J. Alvarado, Carol A.H, Mary AZ. Relation of the inanimate hospital environment to endemic nosocomial infection. The New England Journal of Medicine 2013; 307:25.

8. Goldmann DA, Durbin WA, Freeman J. Nosocomial infections in a neonatal intensive care unit. J Infect Dis 1981; 5:449-59.

9. Durmaz B, Durmaz R, Otlu B, Sonmez E. Nosocomial infections in a new medical center, Turkey. Infect Control Hosp Epidemiol 2000;21:534-6.

10. Mamikoglu L, Gunseren F, Ozcelik FT. Hospital infections in Akdeniz University Hospital: 1994-1995. Turk J Hosp Infect 1998;2:42-5.

11. Metintas S, Akgun Y, Durmaz G, Kalyoncu C. Prevalence and characteristics of nosocomial infections in a Turkish university hospital. Am J Infect Control 2004;32:409-13.

12. Erdinc FS, Yetkin MA, Ataman Hatipoglu C, Yucel M, Karakoc $\mathrm{AE}$, Cevik MA et al. Five-year surveillance of nosocomial infections in Ankara Training and Research Hospital. J Hosp Infec 2006;64:391-6.

13. Vancelik S, Ozden K, Ozkurt Z, Altoparlak U, Aktas E, Savci AB. Hospital infections in Ataturk Universty Medical Faculty Hospitals: results of year 2005. TAF Preventive Medicine Bulletin 2006;5:159-65.

14. Vincent JL, Rello J, Marshall J, Silva E, Anzueto A. International study of the prevalence and outcomes of infection in intensive care units. JAMA 2005;302(21):2323-9.
15. Aydogdu S, Karamese M, Altoparlak U. Evaluation of the Activities of Antimicrobial Agents on Multi-drug Resistant Gram Positive Bacteria Isolated from Intensive Care Units. SOJ Microbiol Infect Dis 2014;2(1):1-5.

16. National Nosocomial Infections Surveillance (NNIS) system report, data summary from October 1986-April 1998, issued June 1998. Am J Infect Control 26(5):522-33.

17. Starnes MJ, Brown CV, Morales IR, Hadjizacharia P, Salim A. Evolving pathogens in the surgical intensive care unit: a 6-year experience. J Crit Care 2008;23(4):507-12.

18. Zeki C, Murat K, Osman A. Prevalence and antimicrobialresistance of Staphylococcus aureus isolated from blood culture in university hospital, Turkey. Glob J Infect Dis Clin Res 2015;1(1):010-013.

19. Calik Z, Acar O, Karamese M, Acar N. Analysis of intensive care units (ICUs) blood stream infections (BSI) in Kafkas University Health Research and Application Hospital. Int J. Microbiol Adv Immunol 2015;03(1):55-9.

20. İnan D, Saba R, Keskin S, Ögünç D, Çifçi C, Günseren $\mathrm{F}$ et al. Akdeniz üniversitesi hastanesi yoğun bakım ünitelerinde hastane infeksiyonları. Yoğun Bakım Dergisi 2002;2(2):129-35.

21. Geyik FM. Dicle üniversitesi hastanesinde nazokomiyal enfeksiyonlar. Hastane Enfeksiyonları Dergisi 2000;4:156-9.

22. Karahocagil MK, Yaman G, Göktaş U, Sünnetçioğlu M, Çı kman A, Bilici A. Hastane enfeksiyon etkenlerinin ve direnç profillerinin belirlenmesi. Van Tıp Dergisi 2011;18 (1):27-32. 